\title{
Cable-stayed coverings for large-span public buildings
}

\author{
Radomir Timchenko ${ }^{1, *}$, Stanislav Popov $^{2}$, Dmitry Krishko ${ }^{1}$, Goodary Rajeshwar ${ }^{3}$, and Aleksej Aniskin ${ }^{4}$ \\ ${ }^{1}$ Kryvyi Rih National University, Civil Engineering Faculty, 11 Vitaliy Matusevych Str., Kryvyi Rih, 50027, Ukraine \\ ${ }^{2}$ Kryvyi Rih National University, Faculty of Information Technologies, 11 Vitaliy Matusevych Str., Kryvyi Rih, 50027, Ukraine \\ ${ }^{3}$ Université des Mascareignes, Faculty of Engineering and Sustainable Development, Department of Civil and Environmental \\ Engineering, Avenue de la Concorde, Roches Brunes, Mauritius \\ ${ }^{4}$ University North, Faculty of Geotechnical Engineering, 1 Trg dr. Žarka Dolinara, Croatia
}

\begin{abstract}
Structural schemes of coverings using lightweight roof structure from modern composite materials are investigated in this paper. A comparison of two options for cable-stayed covering of a circus auditorium, one with an orthogonal mesh of cables (according to a standard design) and another one, with a mesh of cables formed by two groups of stabilizing cables are considered. The possibilities of reinforcement with composite material are analyzed. Calculation and preliminary selection of cable-stayed sections are also carried out and presented. The variations of the conditional volume with the relative sag arrows, for varying values of the coefficient $\mathrm{q}_{\mathrm{k}}$ have been investigated and shown on graphs. An optimization problem was solved and the optimal result with detailed calculations are proposed and presented in this research which enable the design of the cable-stayed coating with determination of its design characteristics. As a result, the optimum and most economical sections of the cable-stayed covering were obtained. The calculations also show the inexpediency of using a heavy roof structure for saddle cable-stayed coverings due to the exclusion of stabilizing cables from the operation with a large roof weight.
\end{abstract}

\section{The problem and its relationship with engineering tasks}

The interest in cable-stayed coverings, which is manifested by many researchers, designers and builders, is common and becoming an actual engineering problem to resolve. This is helped not only by the economic advantages of coatings used, but also by the development of calculation methods and design techniques. Plausible results, associated with the study of static, dynamic and kinematic properties of cable-stayed systems with the use of computer technology, have been achieved. Positive attempts have been made to solve problems of optimal design [1-3].

Currently, scientists are considering issues related to:

- a choice of constructive schemes of a cable-stayed covering;

- study of the stress-strain state of cable-stayed systems;

- methods of solving equations;

- optimal design of cable-stayed systems;

- dynamics of cable-stayed systems;

- construction of cable-stayed coverings;

The relevance of the study is determined by the use of a constructive scheme of coverage, which allows the use of a lightweight roof structure using modern composite materials. The outstanding works of local and foreign scientists in this field over the past 30-40 years are to be commended and encouraging for future research. As a result buildings and structures using cable-stayed systems are quite widespread (coverage of public and industrial long-span buildings, cable-stayed bridges and overpasses) $[4,5]$.

But there are also problems that hinder the spread of cable-stayed systems in construction. This is, first of all, the lack of regulatory framework for the design and calculation of cable-stayed systems. All parameters and recommendations for design and research can be found only in the works of scientists who are specialized in this field.

\section{Analysis of research and publications}

Hanging cable-stayed structures are mainly used to cover large-span buildings (structures) of various types $[1,6]$, such as stadiums, gymnasiums, entertainment and trade buildings, where they are most cost-effective and aesthetically pleasing.

Buildings and structures with cable-stayed (hanging) coating in contrast to the dome and cylindrical coatings, allow to cover the area of buildings (structures) of much larger size without economic losses, while easy to manufacture, install and operate. However, with increasing the area of the cable-stayed cover, respectively, increases the support forces in the cables (flexible threads), which are transmitted to the external support, in which case it is necessary to increase the stiffness parameters of the external support circuit.

Scientists consider issues related to the choice of 
structural schemes of cable-stayed cover, the study of the stress-strain state of cable systems, methods for solving equations, the optimal design of cable systems, the dynamics of cable-stayed systems, the design of cablestayed coverings, among others.

Local and foreign experience of building structures using suspension systems are described in the works of Kirsanov, Dmitrieva, Trushcheva, Faibyshenko, Gorev [7-13].

\section{Formulation of the problem}

The purpose of the study is to analyze the cable-stayed coverings used in long-span public buildings, finding their optimal parameters and choosing an efficient and economical type of roof.

To achieve this, it is necessary to solve the following problems:

- to investigate the state of issues related to the design and calculation of cable systems;

- to find the expedient constructive scheme of a cablestayed covering, to substantiate its choice;

- to study the construction of the roof of cable-stayed coverings, to develop a new type and to adapt it to the chosen structural scheme.

\section{Materials, calculations and results}

The problem of designing a cable-stayed cover is considered on the example of a circus building. It is designed on the basis of a typical circus project. The cable-stayed covering covers the auditorium of the circus with a diameter of $48 \mathrm{~m}$.

The design of the cable-stayed cover took place in several stages:

1st Stage. Choice constructive scheme.

2nd Stage. Choice of roof design.

3rd Stage. Calculation and selection of preliminary sections of cables.

1. Choice constructive scheme.

In the typical project the device of a cable covering in the form of a cable-stayed orthogonal grid is provided. The spatial rigidity of the coating is provided by pre-stress followed by monolithic and transformation of the structure into a shell. The surface has the shape of a hyperbolic paraboloid.

Two directions of cables are the minimum necessary for creation of preliminary pressure (thus the outline of a basic contour corresponds to a grid). However, there are cable-stayed nets formed by three or more directions of cables.

A fairly economical roof solution is a light roof, but it requires a high degree of rigidity of the cable-stayed grid. Therefore, a new kinematic structural scheme is proposed, which is a cable-stayed grid with triangular cells.

Cable-stayed mesh with a triangular structure has the advantage that its elementary triangular cell is always flat. This allows the cells between the cables to be filled with fragile materials, such as glass panels or other materials.

A grid with triangular cells can be formed on any surface.

Thus, for a hyperbolic paraboloid, the supporting cables are directed along the line of the main curvature, and the stabilizing ones - at an angle of $45^{\circ}$ to the main one.

Due to the fact that the existence of right triangles on the surface of a hyperbolic paraboloid is impossible [14, $15]$, it is assumed that the grid nodes will be arranged by forced fastening.

Fig. 1. depicts a cable-stayed grid offered in a typical design and a cable-stayed grid.

Therefore, the designed structural scheme of covering in the form of a cable grid with two groups of stabilizing cables forming triangular cells is used for implementation.

2. Choice of roof design

The maximum weight of lightweight types of roofs is normally limited to $40-60 \mathrm{~kg} / \mathrm{m}^{2}$.

To achieve the normative indicators of heat transfer resistance, the roof is insulated with foam plates with a density of $\rho=0.5 \mathrm{kN} / \mathrm{m}^{3}$ and a thermal conductivity coefficient $\lambda=0.043 \mathrm{~W} / \mathrm{m}^{\circ} \mathrm{C}$.

$R_{0}$ - calculated heat transfer resistance $\mathrm{m}^{2} \cdot{ }^{\circ} \mathrm{C} / \mathrm{W}$ :

$$
R_{0}=\frac{1}{\alpha_{s}}+R_{k}+\frac{1}{\alpha_{u}}
$$

where: $\lambda_{b}-$ heat transfer coefficient of the inner surface of the fence, $\mathrm{W} / \mathrm{m}^{2}{ }^{\circ} \mathrm{C} ; R_{K}$ - thermal resistance of the enclosing structure, $\mathrm{m}{ }^{2 .} \mathrm{C} / \mathrm{W} ; \lambda_{H}$ - heat transfer coefficient (for winter conditions) of the outer surface of

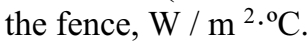

The resistance of steel and waterproofing layer is not taken into account. When designing enclosing structures, it is necessary that their heat transfer resistance is not less than the standard value $R_{0}{ }^{H}$. According to table 1 [16] $R_{0}{ }^{H}$ $=2,6 \mathrm{~m}^{2} \mathrm{C} / \mathrm{W}$ :

$$
R_{0}>R_{0}^{H}
$$

From design requirements 2 plates, $60 \mathrm{~mm}$ thick are acceptable. The resistance to heat transfer is determined:

$R_{0}=1 / 8,7+0.12 / 0,043+1 / 23=0,1149+2,79+$ $+0,0435=2,917 \mathrm{~m}^{2}{ }^{\circ} \mathrm{C} / \mathrm{W}$

$R_{0}=2,917 \mathrm{M}^{2} \cdot{ }^{\circ} \mathrm{C} / \mathrm{BT}>R_{0}{ }^{H}=2,6 \mathrm{~m}^{2}{ }^{\circ} \mathrm{C} / \mathrm{W}$, and as such, the condition is satisfied.

The thickness of the insulation layer is satisfactory.

To fill the triangular cell, a triangular plate of insulation is used, shown in fig. 3 [17]. It is reinforced externally with a composite material.

Let's analyze the possibilities of reinforcement with composite material. Composite materials consisting of a fibrous filler and a binder are suitable for these functions. Such materials are fiberglass and carbon fiber, which are widely used in construction.

Comparison of these materials:

1. Fiberglass - a plastic material consisting of fiberglass filler and binders (thermoactive and thermoplastic polymers). This is a material with a low specific weight and specified characteristics. They have low thermal conductivity, high strength, biological and atmospheric resistance. 


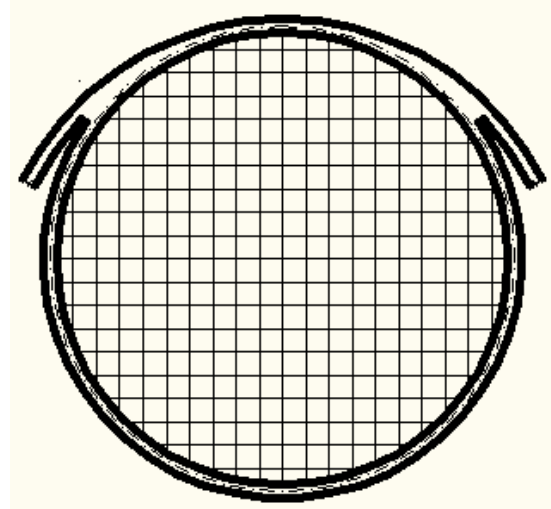

a)

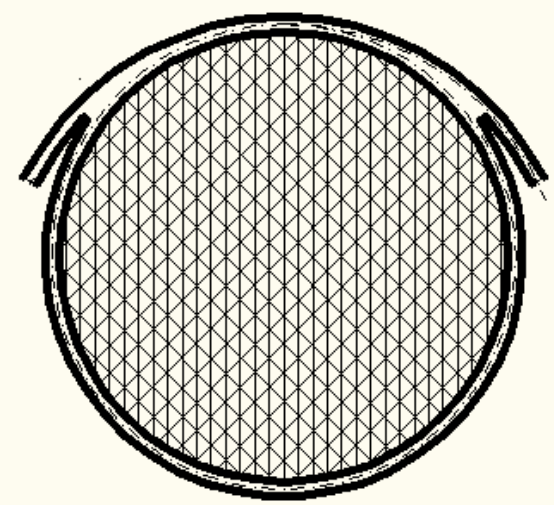

b)

Fig. 1. Cable-stayed cover of the circus auditorium: $a$ - with an orthogonal cable-stayed grid (according to a typical project); $b-$ with a cable-stayed grid formed by two groups of stabilizing cables.

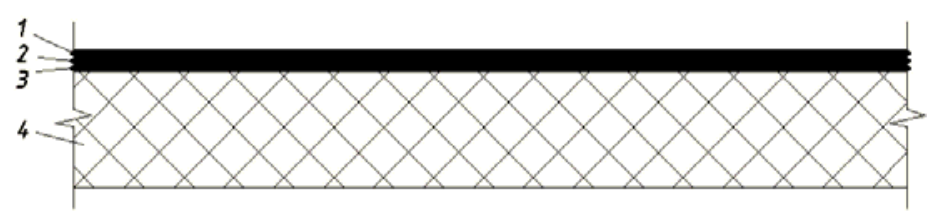

Fig. 2. Roof construction: 1 - waterproofing layer; 2 - metal membrane; 3 - vapor barrier; 4 - insulation.

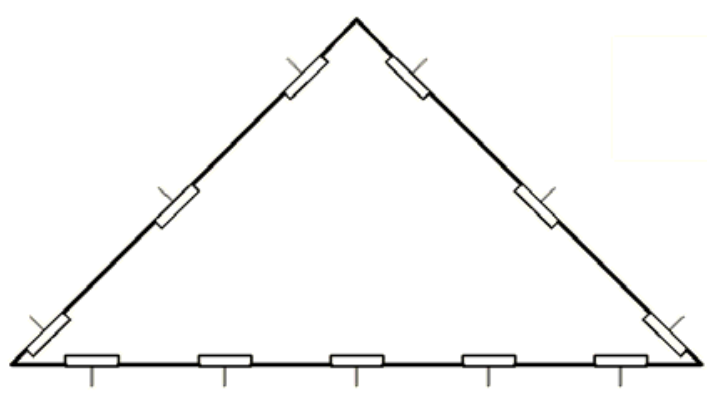

Fig. 3. The scheme of a triangular plate of a heater.

2. Carbon fiber - a material of interwoven threads of carbon fiber, located in a matrix of polymer resins. This material also has low weight and high strength (dominated by specific characteristics of steel). They are also resistant to external influences.

Comparative characteristics of these materials are considered in table. 1 .

As seen from the table, fiberglass and carbon fiber have approximately the same strength characteristics with a lower modulus of elasticity of fiberglass relative to carbon fiber, but the cost of fiberglass is 9-10 times lower. Therefore, it is more appropriate to use fiberglass for external reinforcement.

Reinforcement is performed as follows: two triangular plates of polyfoam are placed on top of each other and fiberglass membrane is laid between them, which is fixed at the edges of metal plates with a thickness of $3 \mathrm{~mm}$, which are fastened together with a bolted connection. This structure is externally reinforced with rolled fiberglass. Fastening of plates among themselves occurs by means of metal welded details of channel section. There are metal hooks which fastens the plate to the cables (fig. 4).
Table 1. Comparative characteristics of reinforcement materials.

\begin{tabular}{|l|c|c|}
\hline \multicolumn{1}{|c|}{ Characteristic } & Fiberglass & $\begin{array}{c}\text { CFRP } \\
\text { (carbon fiber) }\end{array}$ \\
\hline Density, $\mathrm{kg} / \mathrm{m}^{3}$ & $1800-1900$ & $1700-2000$ \\
\hline Modulus of elasticity, GPa & 70 & $140-145$ \\
\hline $\begin{array}{l}\text { Tensile strength (tensile), } \\
\mathrm{MPa}\end{array}$ & 1700 & $800-1100$ \\
\hline Poisson's ratio & $0,2-0,25$ & $0,25-0,3$ \\
\hline $\begin{array}{l}\text { Thermal conductivity, } \\
\mathrm{W} / \mathrm{m}^{\circ} \mathrm{C}\end{array}$ & 0,75 & $0,5-0,1$ \\
\hline $\begin{array}{l}\text { Coefficient of linear } \\
\text { expansion, } 10^{-6}\end{array}$ & $0,45-8,3$ & $0,8-5,2$ \\
\hline $\begin{array}{l}\text { Resistance to aggressive } \\
\text { environments }\end{array}$ & Resistant & Resistant \\
\hline Price, UAH / $\mathrm{m}^{2}$ & $10-14$ & $110-130$ \\
\hline
\end{tabular}

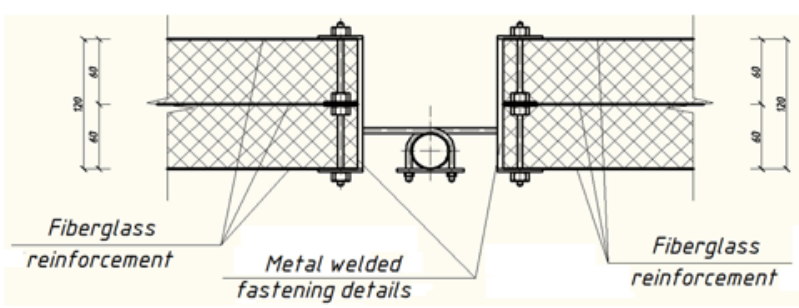

Fig. 4. Knot of fastening of plates to cables.

Fiberglass is additionally glued to metal and foam with CERESIT CT83 polymer-cement adhesive, which works effectively to allow deformation. The joints between the plates are filled with elastic mounting foam, which is resistant to extreme mechanical displacement.

3. Calculation and preliminary selection of sections

The following calculation is suitable for technical and economic comparison. 
Output data:

The cover of the circus auditorium is round in plan, $48 \mathrm{~m}$ in diameter, covered by a cross system of cables, consisting of one group of load-bearing cables and two groups of stabilizers. According to standards [18], the snow load is $1.0 \mathrm{kPa}$, the wind load is 0.88 (taking into account all coefficients). As bearing elements of a grid we accept ropes of double twisting like LK-RO of a design $6 \times 19 \times(1+6+6 / 6+14)+7 \times 7 \times(1+6)$ as per prevailing standards [19] with the coefficient $k_{p}=0.81 \ldots 0.85$ and the temporary resistance of the break wires - 1,764 GPa.

The load on the coating will be entered in table. 2 . Thus wind and snow loading is simply considered to be evenly distributed on a covering surface.

In saddle-shaped coverings (with a surface in the form of a hyperbolic paraboloid) the struts of all bearing ropes will be the same due to the uniform load on the cover and the pressure of the stabilizing ropes on the bearing. As such, we can distinguish one carrier thread, which does not differ in work from others, and one stabilizing thread, which characterizes the same pressures of all stabilizing cables on the carriers.

In design practice, the magnitude of the prestressing system (the magnitude of the forces of interaction of the cables) is often set, provided that the stabilizing cables are almost excluded from operation at full load on the coating. In this case, the share of interaction forces in the total load on the carrier thread is small and the determination of the forces in the grid, carried out by this method of calculation, is accurate enough to assign cross-sections of threads in advance.

Therefore, the forces in the bearing and stabilizing threads are determined by the formulas:

$$
\begin{aligned}
& T_{H}=\frac{d_{H} \cdot l^{2} \cdot a}{8 \cdot f_{u}} \cdot\left[g_{1}+q+p_{1} \cdot\left(\frac{l_{c}^{2}}{C \cdot l_{u}^{2}+l_{c}^{2}}\right)\right] \\
& T_{H}=\frac{d_{c} \cdot l^{2} \cdot a}{8 \cdot f_{c}} \cdot\left[q-g+p_{w} \cdot\left(\frac{C \cdot l_{u}^{2}}{C \cdot l_{u}^{2}+l_{c}^{2}}\right)\right]
\end{aligned}
$$

where: $d$-the steps of the respective cables in the grid (since the stabilizing cables are located at an angle of $45^{\circ}$ to the carriers, then $\left.d=d_{c}=d_{u} \cdot \sqrt{2}\right) ; l_{H}$ and $l_{c}-$ corresponding spans of the supporting and stabilizing cable; $f_{H}$ and $f_{c}$ - corresponding sagging arrows; $g_{1}$ - part of the constant load (own weight of load-bearing structures and connections) applied to the pre-stress $(0.13$ $\mathrm{kPa}) ; q$ required value pre-stressing; $p_{1}$ - temporary (snow) load plus part of the constant load $g_{2}(1,4+0,57=$ $1,97 \mathrm{kPa})$, that is applied after pre-stressing $\left(g_{2}=g-g_{1}\right)$; $g$ - constant load $(0.7 \mathrm{kPa}) ; p_{W}-$ wind load $(1.22 \mathrm{kPa}) ; C$ - the coefficient of interaction of groups of cables; $a=\sqrt{1+16 / n^{2}}$, where: $n=l / f-$ the ratio of the span to the sagging arrow; $q=\left[\left(p_{1} \cdot C\right) /(C+1)\right]+\Delta q$, where $\Delta q-$ additional part of the pre - voltage of the system (it is recommended to take $\Delta q=0,1 \ldots 0,3 \cdot q$;

$$
C=\frac{\mu_{u}^{2}}{\mu_{c}^{2}} \cdot \frac{A_{H} \cdot E_{u} \cdot f_{c}^{2}}{A_{c} \cdot E_{c} \cdot f_{u}^{2}}
$$

where: $\mu_{H}$ and $\mu_{c}-$ appropriate cable extensions $\mu=L / l ; L-$ design length of flexible thread; $A_{H}$ and $A_{c}-$ the corresponding cross-sectional areas of the cables; $E_{k}$ and $E_{c}$ - corresponding modulus of elasticity of cables; $\mu=1+\frac{8 \cdot f_{u}^{2}}{3 \cdot l^{2}}+\frac{\operatorname{tg}^{2} \alpha}{2}$, where $\alpha-$ the angle of inclination to

\begin{tabular}{|c|c|c|c|}
\hline Load & 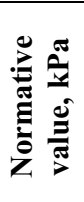 & 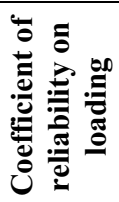 & 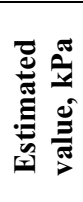 \\
\hline $\begin{array}{l}\text { - own weight of a } \\
\text { cable-stayed grid } \\
\text { (preliminary) } \\
\text { - waterproofing two- } \\
\text { layer rolled carpet of } \\
\text { waterproofing } \\
\text { - steel membrane } \\
t=1 \mathrm{~mm} ; \\
\rho=7800 \mathrm{~kg} / \mathrm{m}^{3} \\
\text { - plates of a heater } \\
t=120 \mathrm{~mm} \\
\rho=0.050 \mathrm{~kg} / \mathrm{m}^{3} \\
- \text { false ceiling }\end{array}$ & $\begin{array}{l}0,08 \\
0,08\end{array}$ & $\begin{array}{l}1,3 \\
1,1\end{array}$ & $\begin{array}{c}0,08 \\
0,3\end{array}$ \\
\hline Total: & 0,59 & 6 & 0,7 \\
\hline $\begin{array}{l}\text { Wind load } \\
\text { Snow load }\end{array}$ & $\begin{array}{c}0,88 \\
1,0\end{array}$ & $\begin{array}{l}1,4 \\
1,4\end{array}$ & $\begin{array}{c}1,23 \\
1,4\end{array}$ \\
\hline
\end{tabular}
the horizontal of the line connecting the supports (fig. 5)

Table 2. Coating load.

As such, for round - in terms of cable-stayed grids from identical cables: $l_{H}=l_{c}$, and $E_{H}=E_{c}$.

Necessary cross-sections of ropes are found by the formulas:

$$
A_{u}=\frac{1,6 \cdot T_{u}}{k_{p} \cdot R_{u n}} \quad A_{c}=\frac{1,6 \cdot T_{c}}{k_{p} \cdot R_{u n}}
$$

where: $R_{u n}$ - temporary resistance of the wire to rupture.

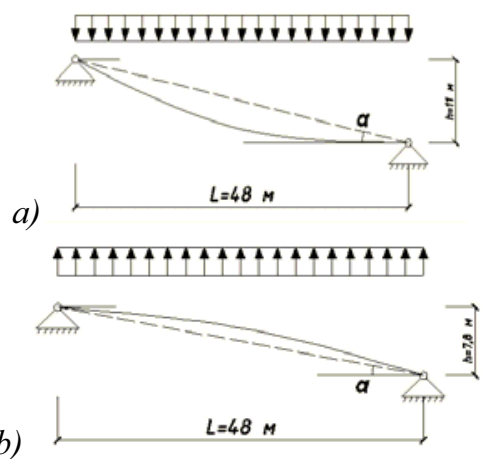

Fig. 5. Calculation schemes of cables: $a$ - carrier, $b$ stabilizing.

As can be seen from the above formulas, the crosssectional area of the ropes depends on several factors:

1. arrows sagging ropes;

2. the magnitude of the pre-stress;

3 . the coefficient of interaction of groups of cables;

4. the step of the cables in the grid, which also 
indirectly affects each other.

Therefore, to find the cross sections of the ropes (they should be the smallest) it is necessary to solve the optimization problem. As a target function, we use the relative volume of metal in the cables:

$$
F=\sum L_{u} \cdot A_{u}+\sum L_{c} \cdot A_{c} \rightarrow \min
$$

where the sum of the lengths of the cables is as follows:

$$
\begin{aligned}
& \sum L_{u}=\mu_{u} \cdot\left(2 \cdot \sum_{2}^{n} l_{u i}+l_{u}\right) \\
& \sum L_{c}=\mu_{c} \cdot\left(2 \cdot \sum_{2}^{b} l_{c j}+l_{c}\right)
\end{aligned}
$$

where: $n=R / d_{u}$ and $m=R / d_{c} ; R$ - coverage radius in the plan. Formulas (8) and (9) can be rewritten as:

$$
\begin{aligned}
& \sum L_{u}=\mu_{n} \cdot \frac{S_{\text {coating }}}{d} \\
& \sum L_{c}=2 \cdot \mu_{c} \cdot \frac{S_{\text {coating }}}{d \cdot \sqrt{2}}
\end{aligned}
$$

$S_{\text {coating }}=\pi \cdot 24^{2}=1809 \mathrm{M}^{2}$.

Let's set the limits of variables:

1) Instead of sagging arrows, relative sagging arrows are used: $D_{u}=f_{u} / l_{l}$, та $D_{c}=f_{c} / l_{c}$. According to the recommendations [25], they vary within: $D_{H}=1 / 15 \ldots 1 / 8, D_{c}=1 / 25 \ldots 1 / 10$.

2) The magnitude of the pre-stress will be characterized by a coefficient $q_{k}=(q+\Delta q) / q$, which varies within $1,1 \ldots 1,3$.

3) The coefficient of interaction of groups of cables will depend on the coefficient $B=A_{s} / A_{n}$, which is recommended to take $0.3 \ldots 0.5$ [25].

Taking into account all the formulas, certain dependencies and initial data, we finally have:

Target function:

$$
F=\mu_{u} \cdot \frac{1809}{d} \cdot A_{u}+2 \cdot \mu_{c} \cdot \frac{1809}{d \cdot \sqrt{2}} \cdot A_{c}
$$

where: $\quad A_{n}=T_{n} \cdot 11,8 \cdot 10^{-9} ; \quad A_{c}=T_{c} \cdot 11,8 \cdot 10^{-9}$;

$$
\begin{gathered}
T_{u}=\frac{d \cdot 6 \cdot a}{D_{u}} \cdot\left[0,13+q+1,97 \cdot\left(\frac{1}{C+1}\right)\right] ; \\
T_{c}=\frac{d \cdot \sqrt{2} \cdot 6 \cdot a}{D_{c}} \cdot\left[q-0,7+1,22 \cdot\left(\frac{1}{C+1}\right)\right] ; \\
q=\frac{1,97 \cdot C}{C+1} \cdot k_{q} ; \quad C=\frac{\mu_{u}^{2}}{\mu_{c}^{2}} \cdot \frac{D_{c}^{2}}{D_{u}^{2}} \cdot B ; \\
a_{u}=\sqrt{1+16 \cdot D_{u}} ; \quad a_{c}=\sqrt{1+16 \cdot D_{c}} ; \\
\mu_{n}=1,053+\frac{8 \cdot D_{u}}{3} ; \quad \mu_{c}=1,026+\frac{8 \cdot D_{c}}{3} ;
\end{gathered}
$$

Limitation:

$-D_{H}=1 / 15 \ldots 1 / 8, D_{c}=1 / 25 \ldots 1 / 10$;

$-q_{k}=1,1 \ldots 1,3$;

$-B=0,3 \ldots 0,5$.

It can be seen that the target function does not depend on the pitch of the cables in the grid. Therefore, we assign it from the design requirements: the largest side of the triangular cell is taken as $3 \mathrm{~m}$, hence $\mathrm{d}=1.5 \mathrm{~m}$.

There is also another requirement - the deformability of the coating which is as follows:

$$
\Delta f=\frac{3}{128} \cdot \frac{\mu_{H}^{2}}{f_{H}^{2}} \cdot \frac{p \cdot l^{4}}{E \cdot A_{H}} \leq \frac{l}{200}
$$

where: $p$ - snow load.

The solution of the optimization problem is performed in Microsoft Excel, with the help of the "Search solution" function.

The results are presented in tables 3 and 4 .

Table 3. Initial data.

\begin{tabular}{|l|c|}
\hline Coverage radius in the plan, $\mathrm{m}$ & 24 \\
\hline & \\
\hline load: & 0,7 \\
\hline permanent: & 0,13 \\
\hline - to voltage, $\mathrm{kPa}$ & 0,57 \\
\hline - after stress, $\mathrm{kPa}$ & 1,4 \\
\hline Temporary (snow), $\mathrm{kPa}$ & 1,22 \\
\hline Wind, $\mathrm{kPa}$ & \\
\hline & 1,764 \\
\hline $\begin{array}{l}\text { Temporary resistance of a wire of a rupture, } \\
\text { GPa }\end{array}$ & 0,81 \\
\hline Coefficient of working conditions & 160 \\
\hline Modulus of elasticity of ropes, GPa \\
\hline
\end{tabular}

According to the obtained values of the cross-sectional area, we select ropes by assortment.

Thus the ropes of the bearing group - Ø33 $\mathrm{mm}$ with $\mathrm{A}_{\mathrm{H}}=4,977 \mathrm{~cm}^{2}$, the stabilizing group -2 ropes Ø $12,5 \mathrm{~mm}$ with $\mathrm{A}_{\mathrm{c}}=1.4182 \mathrm{~cm}^{2}$

Deformability of the coating $0,03<48 / 200=0.24$. All conditions are met and the optimum solution is found.

To connect the cables to each other, a metal plate is used, to which the cables are fastened with a bolted connection (Fig. 6,7). Fastening of cables in knot is compulsory.

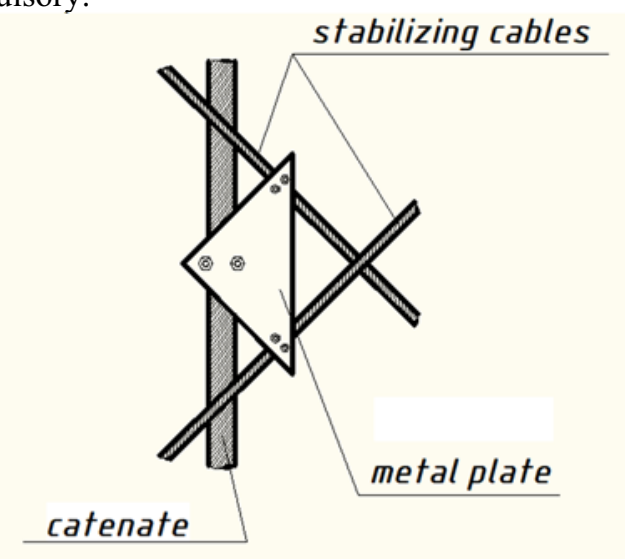

Fig. 6. Knot of fastening of cables among themselves.

Reinforced concrete support ring is designed prefabricated monolithic type. The reference circuit is partially prefabricated.

The cables are attached to the embedded parts on the side elements by means of a wedge-sleeve anchor. After adjusting the position of the cables, the contour is added to the design dimensions. 


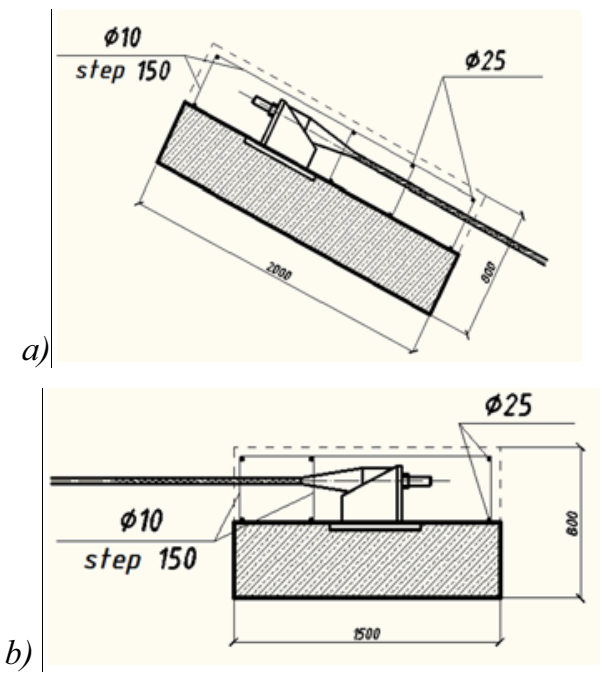

Fig. 7. Knots of adjoining of cables to a basic reinforced concrete ring: $a$ - adjoining to the top onboard element, $b$-adjoining to the lower onboard element.

Table 4. The result of the optimization problem

\begin{tabular}{|c|c|c|c|}
\hline $\begin{array}{l}\text { Target function, } \mathrm{m}^{3} \text { of } \\
\text { metal }\end{array}$ & & 0,809 & \\
\hline \multicolumn{4}{|l|}{ Cross section of cables: } \\
\hline - stabilizing, $\mathrm{cm}^{2}$ & & 1,362 & \\
\hline - bearing, $\mathrm{cm}^{2}$ & & 4,540 & \\
\hline $\begin{array}{l}\text { Step of bearing cables } \\
(d), \mathrm{m}\end{array}$ & & 1,5 & \\
\hline \multicolumn{4}{|l|}{ Effort in cables: } \\
\hline - bearing, $\mathrm{kN}$ & & 405,427 & \\
\hline - stabilizing, $\mathrm{kN}$ & & 121,663 & \\
\hline Variables & \multicolumn{3}{|c|}{ value } \\
\hline & $\min$ & optimal & $\max$ \\
\hline \multicolumn{4}{|l|}{$\begin{array}{l}\text { Relative arrows sagging } \\
\text { guys }\end{array}$} \\
\hline- stabilizing $\left(D_{c}\right)$ & 0,04 & 0,100 & 0,1 \\
\hline - carriers $\left(D_{H}\right)$ & 0,067 & 0,076 & 0,125 \\
\hline Coefficient kq & 1,1 & 1,30 & 1,3 \\
\hline Coefficient B & 0,3 & 0,3 & 0,5 \\
\hline $\begin{array}{l}\text { The value of the } \\
\text { deformability of the } \\
\text { coating }(\Delta f)\end{array}$ & & 0,029 & 0,24 \\
\hline \multicolumn{4}{|l|}{ Additional values } \\
\hline $\begin{array}{l}\text { The magnitude of the } \\
\text { prestress, } q\end{array}$ & & 0,876 & \\
\hline Coefficient $C$ & & 0,520 & \\
\hline \multicolumn{4}{|l|}{$\begin{array}{l}\text { Elongation of cables } \\
(\mu) \text { : }\end{array}$} \\
\hline - stabilizing & & 1,040 & \\
\hline - bearing & & 1,042 & \\
\hline \multicolumn{4}{|l|}{ The coefficient $\alpha$} \\
\hline - bearing & & 1,489 & \\
\hline - stabilizing & & 1,612 & \\
\hline
\end{tabular}

Fig. 8 shows the curves of the conditional volume of the cables for different values of the relative sagging arrows of the stabilizing and supporting cables, at different values of the coefficient $q_{k}$. The graphs show that the most economical are the options with $q_{k}=1.3$ and with larger values of the sagging arrows of the supporting cables.
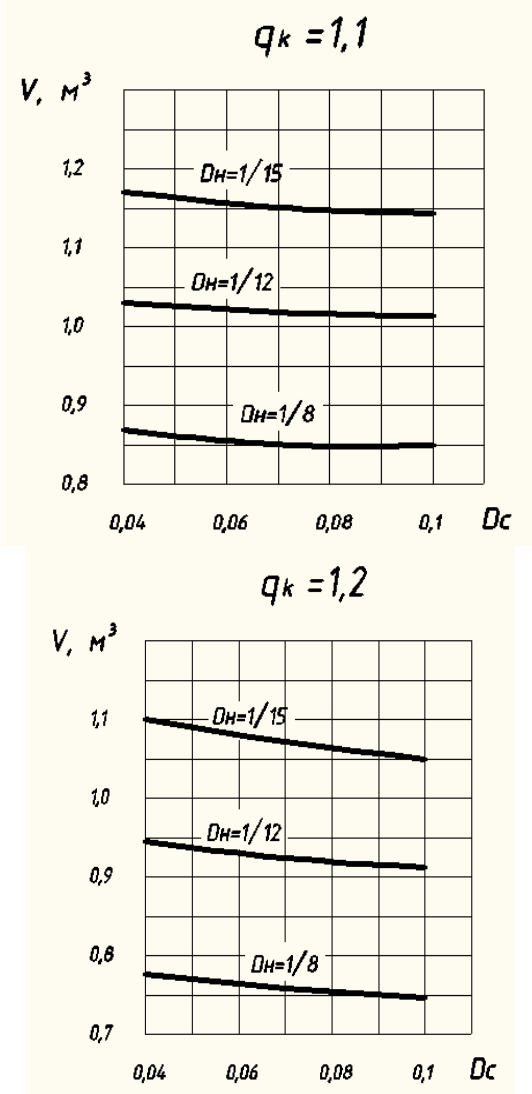

$q_{k}=1,3$

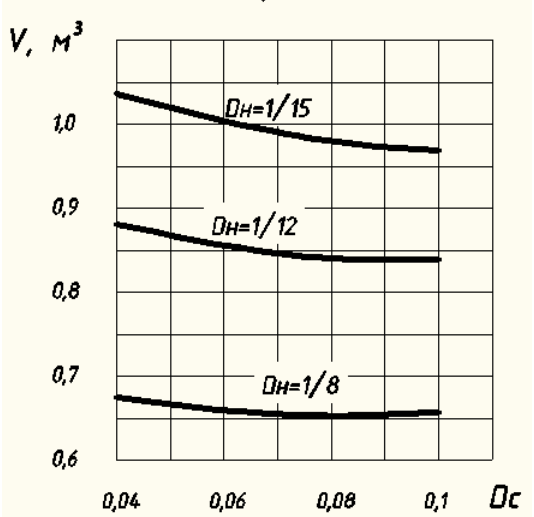

Fig. 8. Variation of the conditional volume with the relative sagging arrows, at values of the coefficient $q_{k}$.

The next step is to perform the same operation for a typical option - orthogonal mesh.

Calculations are performed according to the same formulas, but taking into account that the step in the grid is the same, that is, $2,4 \mathrm{~m}$.

The load on the coating will be entered in table 5 .

The solution of the optimization problem is entered in tables 6 and 7 .

As can be seen from the table, this problem has no solution, as the force in the stabilizing cable is close to zero. This is due to the fact that the coating is stabilized due to its own weight, and therefore the stabilizing cables are almost not included in the functioning of the structure.

By assortment we find the necessary ropes. Ropes of the bearing group $-2 \varnothing 36 \mathrm{~mm}$ with $A_{H}=11,7962 \mathrm{sm}^{2}$, 
stabilizing ropes are assigned the same from the design conditions.

Table 5. Load on the coating.

\begin{tabular}{|c|c|c|c|}
\hline Load & 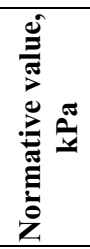 & 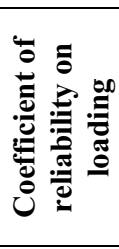 & 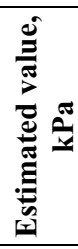 \\
\hline $\begin{array}{l}\text { - own weight of a cable } \\
\text { grid (preliminary) }\end{array}$ & 0,12 & 1,1 & 0,13 \\
\hline $\begin{array}{l}\text { - waterproofing two- } \\
\text { layer rolled carpet of } \\
\text { waterproofing } \\
\text { - asphalt screed } \\
t=15 \mathrm{~mm} ;\end{array}$ & 0,08 & 1,3 & 0,1 \\
\hline $\begin{array}{l}\rho=1800 \mathrm{~kg} / \mathrm{m}^{3} \\
- \text { metal membrane }\end{array}$ & 0,27 & 1,3 & 0,46 \\
\hline $\begin{array}{l}t=1 \mathrm{~mm} \\
- \text { plates of a heater } \\
t=60 \mathrm{~mm}\end{array}$ & 0,08 & 1,1 & 0,09 \\
\hline $\begin{array}{l}\rho=0.050 \mathrm{~kg} / \mathrm{m}^{3} \\
-\quad \text { reinforced concrete }\end{array}$ & 0,03 & 1,3 & 0,05 \\
\hline $\begin{array}{l}\text { slabs } t_{\text {priv }}=53 \mathrm{~mm} \\
\rho=2500 \mathrm{~kg} / \mathrm{m}^{3}\end{array}$ & 1,54 & 1,1 & 1,7 \\
\hline - filling of seams & 0,2 & 1,1 & 0,7 \\
\hline - false ceiling & 0,25 & 1,2 & 0,3 \\
\hline Total: & 2,57 & 9,5 & 3,75 \\
\hline Wind load & 0,88 & 1,4 & 1,23 \\
\hline Snow load & 1,0 & 1,4 & 1,4 \\
\hline
\end{tabular}

Table 6. Initial data.

\begin{tabular}{|l|c|}
\hline Coverage radius in the plan, $\mathrm{m}$ & 24 \\
\hline load: & \\
\hline permanent: & 2,96 \\
\hline - to voltage, $\mathrm{kPa}$ & 0,13 \\
\hline - after stress, $\mathrm{kPa}$ & 2,83 \\
\hline Temporary (snow), $\mathrm{kPa}$ & 1,4 \\
\hline Wind, $\mathrm{kPa}$ & 1,22 \\
\hline Temporary resistance of a wire of a rupture, $\mathrm{GPa}$ & 1,764 \\
\hline Coefficient of working conditions & 0,81 \\
\hline Modulus of elasticity of ropes, $\mathrm{GPa}$ & 160 \\
\hline
\end{tabular}

It is possible to investigate the dependence of the degree of operation of the stabilizing cables on the load on the coating. In fig. 9 and 10 show graphs illustrating this phenomenon.

The graphs show that the most effective stabilizing cable works at a load of $0.5-1.2 \mathrm{kPa}$, at a load of 2.6-3.0 $\mathrm{kPa}$ it becomes ineffective, and at lower values also begins to perform the functions of the supporting cable. From which it can be concluded that the most rational type of roof for saddle-shaped cable-stayed structures is a light roof.

According to the design organizations and the analysis of the indicators of the constructed buildings, the relative cost of cable coverings is:

- 56-60\% of the cost of prefabricated reinforced concrete shell;

$-40-44 \%$ of the cost of coating on steel arches;

$-35-39 \%$ of the cost of the lattice steel coating.
Table 7. Solution of the optimization problem.

\begin{tabular}{|l|c|c|c|}
\hline Target function, $\mathrm{m}^{3}$ of metal & & 0,919 & \\
\hline Cross section of cables: & & & \\
\hline- stabilizing, $\mathrm{cm}^{2}$ & & 0 & \\
\hline - bearing, $\mathrm{cm}^{2}$ & & 11,516 & \\
\hline Step of bearing cables $(d), \mathrm{m}$ & & 2,4 & \\
\hline Effort in cables: & & & \\
\hline - bearing, $\mathrm{kN}$ & & 1028,393 & \\
\hline - stabilizing, $\mathrm{kN}$ & \multicolumn{3}{|c|}{ value } \\
\hline Variables & min & optimal & min \\
\hline & & & \\
\hline Relative arrows sagging guys & 0,04 & 0,1 & 0,1 \\
\hline - stabilizing $\left(D_{c}\right)$ & 0,067 & 0,117 & 0,125 \\
\hline - carriers $\left(D_{H}\right)$ & 1,1 & 1,3 & 1,3 \\
\hline Coefficient $k_{q}$ & 0,3 & 1,0 & 0,5 \\
\hline Coefficient $B$ & & 0,020 & 0,24 \\
\hline $\begin{array}{l}\text { The value of the deforma- } \\
\text { bility of the coating }(\Delta f)\end{array}$ & & & \\
\hline Additional values & & 2,423 & \\
\hline $\begin{array}{l}\text { The magnitude of the } \\
\text { prestress, } q\end{array}$ & & 0,787 & \\
\hline Coefficient $C$ & & & \\
\hline Elongation of cables $(\mu):$ & & 1,027 & \\
\hline- stabilizing & & 1,062 & \\
\hline- bearing & & 1,693 & \\
\hline The coefficient $\alpha$ & & 1,613 & \\
\hline- bearing & & & \\
\hline- stabilizing & & & \\
\hline & & & \\
\hline
\end{tabular}

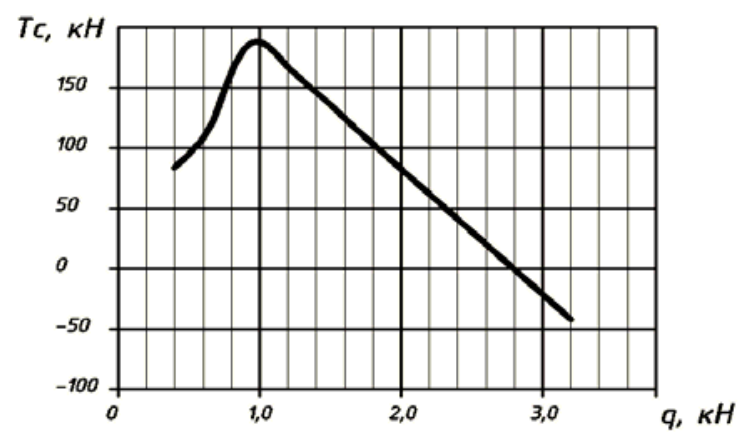

Fig. 9. The dependence of the tension of the stabilizing cable on the load on the coating

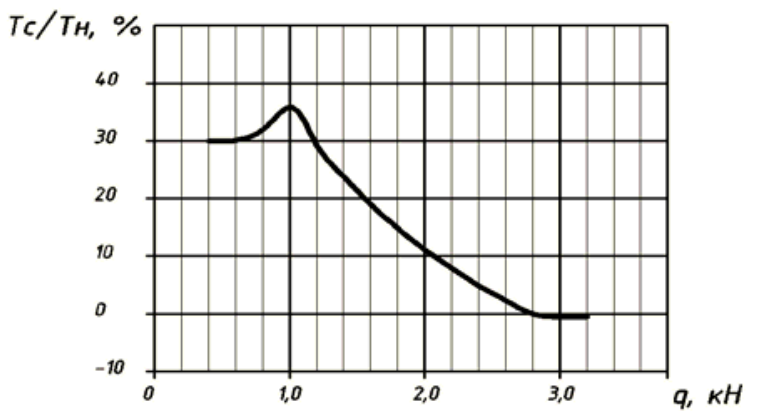

Fig. 10. Dependence of relative tension of stabilizing cables (\%) on loading.

In fig. 11 shows the average relative costs of steel and concrete for different types of coatings.

Fig. 12 and 13 show the costs of steel and concrete for different roofing systems of public buildings. 

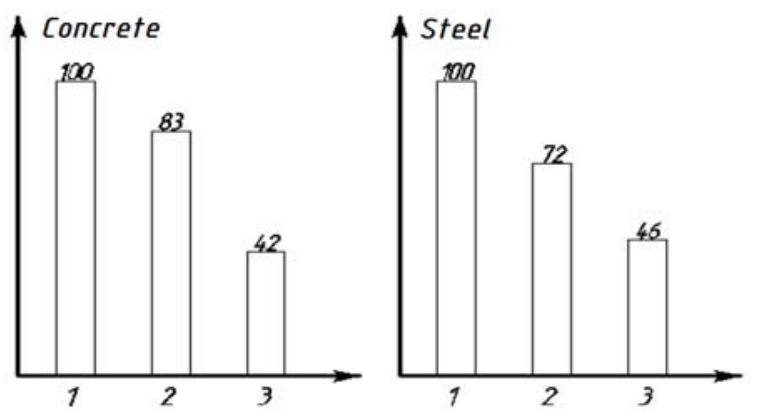

Fig. 11. Relative costs of concrete and steel for: 1 - coating of typical beam elements; 2 - covering from prefabricated reinforced concrete vaults-shells; 3 - cable-stayed cover.

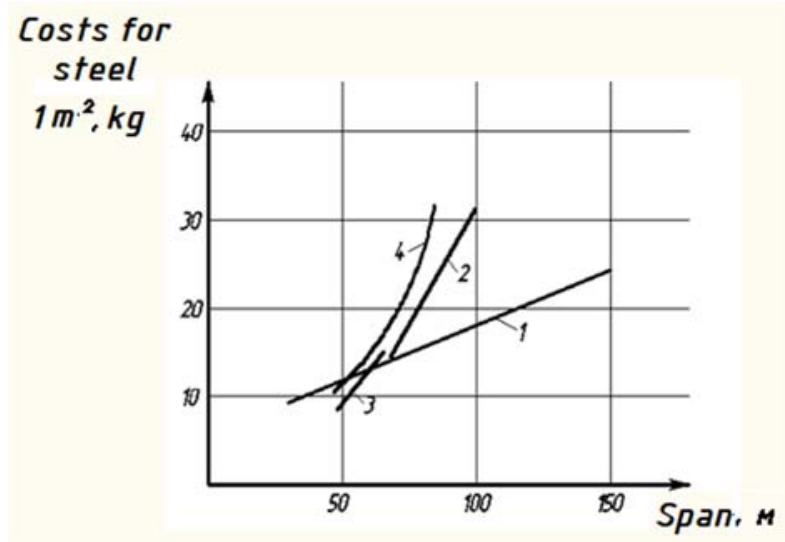

Fig. 12. Costs of steel per $\mathrm{m}^{2}$ of coating for: 1 - cable coating; 2 - reinforced concrete shells; 3 - beam reinforced concrete structures; 4 - coating on steel trusses.

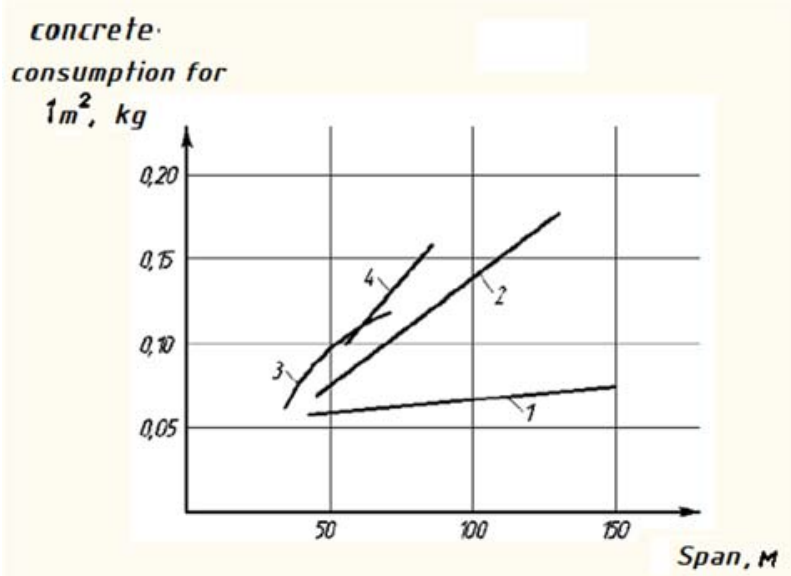

Fig. 13. The cost of concrete per $\mathrm{m}^{2}$ of coating for: 1 - cable cover; 2 - reinforced concrete shells; 3 - beam reinforced concrete structures; 4 - coating with reinforced concrete slabs.

Finally, from the above characteristics, it can be seen that the cable cover is a more economical type of coating, especially with large spans.

\section{Conclusions}

Cable-stayed structures are more economical compared to other types of roofs, but their widespread use today is complicated by the lack of design and calculation standards, as well as design solutions dated $30-40$ years ago.

The constructive scheme of a cable-stayed covering formed by two groups of stabilizing cables is presented and it is shown that an elementary triangular cell is formed, which allows the use of fragile roofing materials.

A new type of coating plate is proposed, consisting of triangular plates of fiberglass-reinforced insulation. This makes it possible to facilitate the design of the coating without reducing the strength characteristics.

An optimization problem was solved to design the cable-stayed cover and determine its characteristics. As a result, the optimal cross-sections of the cables were obtained. For comparison, the optimization problem for a typical coating variant was also solved.

The calculation shows the inexpediency of using a heavy roof structure for saddle-shaped cable-stayed coverings due to the exclusion from the work of stabilizing cables with a large weight of the roof.

The developed design of a cable covering is more economical in comparison with a typical design of a roof, with reduced materials and more effective performance of the elements.

\section{References}

1. E.R. Kuzhakhmetova, A.I. Sapozhnikov, Arhitekturnaja vyrazitel'nost' $i$ fiziologicheskaja celesoobraznost' zdanij s krivolinejnymi poverhnostjami (Architectural expressiveness and physiological feasibility of buildings with curved surfaces). Building materials, equipment, technologies of the XXI century, 11 (166), 42-45 (2012).

2. V.S. Semenov, Sovremennye prostranstvennye konstrukcii: sintez iskusstva, tehniki i nauki (Modern spatial constructions: a synthesis of art, technology and science). (Publishing house of KRSU, Bishkek, 2010).

3. P.G. Eremeev, Sovremennye stal'nye konstrukcii bol'sheproletnyh pokrytij unikal'nyh zdanij $i$ sooruzhenij (Modern steel structures of large-span coatings of unique buildings and structures). (ACB, Moscow, 2009).

4. L.F. Shubin, I. L. Shubin, Arhitektura grazhdanskih $i$ promyshlennyh zdanij (Architecture of civil and industrial buildings). (BASTET, Moscow, 2010).

5. N.V. Kancheli, Stroitel'nye prostranstvennye konstrukcii (Building spatial structures). (ACB, Moscow, 2008).

6. A.I. Sapozhnikov, Zhizn' zdanij v zemnoj stihii (Life of buildings in the earth element). (LAP Lamber Academic Publishinq, Germany, 2014).

7. S.N. Krivoshapko, Visjachie trosovye konstrukcii $i$ pokrytija sooruzhenij (Hanging wire rope structures and structure coverings). Construction of unique buildings and structures, 7 (34), 51-70 (2015).

8. S.N. Krivoshapko, Vantovye struktury (Cable-stayed structures). Structural mechanics of engineering 
structures and structures, 1, 9-22 (2016).

9. K.Park, M.Park, S.Shin, Design of large space cable roofs with retractable systems to open and close (International Journal of Latest Trends in Engineering and Technology), 8, Issue 4-1, 197-203 (2017). http:// dx.doi.org/10.21172/1.841.34

10. G. Grunwalda, T.Hermekingb, T.Prangc, Kinetic Roof Structure: Msheireb Heart of Doha (Procedia Engineering), 155, 89-96 (2016).

11. E. Yu. Ageeva, V. A. Tishkov, A. E. Filimonova, Konstruktivnye osobennosti visjachih pokrytij $v$ obshhestvennyh zdanijah (Design features of hanging roofs in public buildings). (NNSUACE, N. Novgorod, 2015).

12. V.V. Gorev, B.Yu. Uvarov, V.V. Filippov, B.I. Belyj, Metallicheskie konstrukcii (Metal structures). (Higher school, Moscow, 2004).

13. S. D. Fedotov, A.V. Ulybin, Obsledovanie vantovogo pokrytija sportivnogo kompleksa «Jubilejnyj»v g. Sankt-Peterburg (Examination of the cable-stayed covering of the sports complex "Yubileiny" in St. Petersburg). (Publishing house of the Polytechnic University, St. Petersburg, 2015).
14. V.V. Mikhailov, Predvaritel'no naprjazhennye kombinirovannye sterzhnevye vantovye konstrukcii (Prestressed combined rod cable-stayed structures). (ACB, Moscow, 2002).

15. M.S. Tupolev, Konstrukcii grazhdanskih zdanij (Civil building structures). (Architecture-C, Moscow, 2006).

16. DSTU-N B B.1.1-27:2010,Budivel'na klimatologija (Construction climatology). (Ministry of Regional Development of Ukraine, Kyiv, 2011).

17. R.O.Timchenko, D.A.Krishko, A.V.Bogatynsky Pat. 93093 Ukraine, Polegshena plita pokrittja (Lightweight coating plate), № 201311457; Application 27.09.2013; Publ. 25.09.2014, Bull. № $18 .-$ p. 6 .

18. DBN B.2.6-198: 2014, Stalevi konstrukciï. Normi proektuvannja (Steel structures. Design standards). (Ministry of Regional Development of Ukraine, Kyiv, 2014).

19. V.K. Fedulov, M.D. Suladze, L.Yu. Artemova, Vantovye pokrytija (Cable-stayed coatings). (MADI, Moscow, 2014). 